Вісник Дніпропетровського університету. Серія: Геологія, географія Vìsnik Dnìpropetrovs'kogo unìversitetu. Serìa Geologiâ, geographîa

Dnipropetrovsk University bulletin. Seria: Geology, geography

Dnipropetr. Univ. Bull. Ser.: Geol., geogr. 2015. 23(1), 75-82.

doi: $10.15421 / 111509$

ISSN 2313-2159 print

ISSN 2409-9864 online

http://geology-dnu.dp.ua

УДК 502.76:55(477)

Geological Heritage and Geoscience education in Ukraine

\author{
V.V. Manyuk \\ Oles Honchar Dnipropetrovsk National University, Dnipropetrovsk, Ukraine
}

\begin{abstract}
Ukraine has a long history of campaigning for the preservation of not only the biological but also the geological component of the natural environment. The first society for the protection of nature in the history of the Russian Empire was created in Ukraine in 1910. The aim of the society was to protect both the animal and the mineral kingdoms of the natural environment. Since 1992 Ukrainian geologists have been taking part in the meetings of the European working group (EWGFSC-the future ProGEO), and since 2000 have been members of the Central European Group of ProGEO. One of the symposiums ProGEO 2006 year took place in Ukraine and it was no accident that this allowed us to develop and include in the curriculum of students of geological specialities of Dnipropetrovsk National University a new course: «The Study and Preservation of Natural Geological Monuments (Geosites)», which has been taught from 2012. The training course includes the history of the origin and development of the movement for the conservation of the geological heritage, examples of geoconservation in Europe and the world, the legal framework regarding the Nature Reserve Fund of Ukraine as a whole and its geological component in particular, methodological principles of generating a network of geosites in Ukraine, the criteria for the selection of geosites at local, national, European and international levels, and more.

Key words: Geological monuments (geosites), geological heritage, geoconservation, Nature
\end{abstract} Reserve Fund, new course of lectures.

\title{
Геологічна спадщина та геологічна освіта в Україні
}

\section{В. В. Манюк}

Дніпропетровський національний університет імені Олеся Гончара

Україна має тривалу історію руху за збереження як біологічної так i геологічної складової навколишнього природного середовища. Перше в історії Росії товариство охорони

Дніпропетровський національний університет імені Олеся Гончара, просп. Гагаріна, 72, Дніпропетровськ, 49010, Україна.

Oles Honchar Dnipropetrovsk National University, pr. Gagarina, 72, Dnipropetrovsk, 49010, Ukraine.

Tel.: +38-067-947-45-04. E-mail: manuk-geo@ mail.ru 
природи було створено в Україні в 1910 році. Метою товариства було взяти під захист як об'єкти живої природи, так і мінеральне царство природи. Геологи України вже 31992 року беруть участь у зустрічах Європейської робочої групи (EWGFSC - майбутньої ПроГЕО), а 32000 присдналися до Центральносвропейської групі ПроГЕО. Один 3 симпозіумів ПроГЕО в 2006 році проходив в Україні і не випадково стало можливим розробити і включити в програму навчання студентів геологічних спеціальностей Дніпропетровського національного університету новий курс: «Вивчення та збереження геологічних пам'яток природи (геосайтів)», який викладається з 2012 року. У навчальному курсі розглядається історія виникнення та розвитку руху за збереження геологічної спадщини, приклади геоконсерваціі в країнах Європи та світу, законодавча база щодо природно-заповідного фонду України в цілому і його геологічної складової зокрема, методологічні засади формування мережі геосайтів в Україні, критерії відбору геосайтів для місцевого, державного, свропейського та міжнародного рівнів і багато іншого.

Ключові слова: геологічні пам'ятки (геосайти), геологічна спадщина, геоконсервація, природно-заповідний фонд, новий курс лекцій.

Introduction. For the first time in the history of the movement for the conservation of the geological heritage a course on the study and conservation of natural geological monuments (geosites) has been introduced into the curriculum students of Ukraine. There are some teaching experiences on geoconservation in Europe. For example in Romania Geoeducation is considered to be a key part of Geoconservation. Alexandru Andrasanu presents geoeducation as an integral part of the activity and structure of geoconservation and prepared an educational package for secondary schools and university curriculum [1]. The methodology used includes research studies on geoconservation in the national curricula, student opinion analysis, case studies from Romania and other countries, development of new educational tools and basic requirements for specialists in geoconservation. Geoeducation has to be considered in a broader perspective as part of education for nature conservation and ultimately part of educational strategy, which is required to be set up in partnership with schools, universities, and local councils, in order to develop training packages and courses for local teaching staff and students, to organize events for natural heritage [1].

In 2005 a major step was taken by the University of Minho (Portugal) with the creation of a master course on Geological Heritage and Geoconservation. This 2-year course (120 ECTS) was at the time the only post-graduate degree totally dedicated to this domain. During the first year, students have to complete several multidisciplinary modules including: Geodiversity; GIS and Computers applied to Geoconservation; Inventorying, Conservation and Interpretation of Geological Heritage; Environmental Legislation; Geotourism; Education for Sustainable Development etc.

In the academic year 2006-2007, a course on Turkey's Geological Heritage, Geotourism and its Potential for Geoparks was offered as an optional subject to the students at the Department of Geology, Faculty of Engineering, Dokuz Eylul University for the first time. Students from the Geology, Geophysics, Mining and Environmental Engineering Departments have been enrolled in this course. During this course, concepts of geological heritage, geosites, geoparks, and why and how they should be preserved and protected are explained to the students.

Geoheritage is partly included in lectures at the Department of Geology, Faculty of Science, and University of Zagreb. Prof. Juračić included the basics of Geoheritage in his lectures on Environmental Geology.

In addition, Albania for the first time included the subject: Cultural and Natural Heritage of Albania in the curriculum for secondary schools. The text book was 
compiled and published by Dr. Merita DOLLMA, geographer, member of ProGEO Albania.

In Slovenia a «Summer Camp for Geology Students» was organized by students and part of the camp activities included a short introduction to conservation of geological heritage.

The course was included in the curriculum of students of geological specialties at Dnepropetrovsk National University Oles Honchar in 2012.The study and preservation of The course was included in the curriculum of students of geological specialties at Dnepropetrovsk National University Oles Honchar in 2012.The study and preservation of the geological heritage has a long tradition in Ukraine. The first Russian society for nature conservation was created in 1910 in Ukraine, then part of the Russian Empire [9].

The society was organized in Ekaterinoslav province in the city of Aleksandrovsk (now Zaporizhia), on the initiative of the teachers of Hortitsky Central School of Peter Buzuk. The scope of the society, according to its statute, included not only wildlife, but also the natural mineral kingdom. One of the earliest examples of its activity was the decision to purchase the rocks on the Dnieper River from their private owners in order to save them from destruction.

In 1928, for the first time on the territory of Russia, in the city of Ekaterinoslav (Dnepropetrovsk), the first geological natural monument (geosite) was created on the initiative of geologist M. Leshchenko. These were the scenic cliffs on Monastery Island in the City Park Shevchenko. The rocks belong to the Middle Achaean and have the absolute age of 3.2 billion years.

The further history of the study and preservation of the geological heritage of Ukraine is filled with many important events and actions to realise the idea of conservation of the geological heritage.

A new stage of significantly increased activity in preserving the geological heritage was marked by the creation of the European Association for the Conservation of the Geological Heritage (ProGEO), which Ukraine has joined [7].

Ukrainian scientists joined the Central European Group (ProGEO) and have participated in all the meetings of ProGEO. Since then, a gradually changing attitude to the problem of conservation of inanimate nature has grown up in the country. Appreciation of the need for geoconservation has developed to the same extent as that for bioconservation. The geological environment is the most important component of the natural environment and is protected by the legislation of Ukraine as a national asset to which is directed a special regime of protection, restoration and management. Ukraine considers its Nature Reserve Fund as part of the global system of natural areas and objects which are under special protection. The objective of the legislation of Ukraine on the Nature Reserve Fund of Ukraine is to regulate social relations regarding the organization, protection and use of territories and objects which are under special protection.

Material and methods of research. The course emphasizes the history and development of the movement for the conservation of the geological heritage in Ukraine and in other countries of the world. It considers in detail the emergence and development of the European Association for the Conservation of the Geological Heritage (ProGEO), its main meetings, conferences and symposia, adopted declarations and the role of ProGEO in the development of the evaluation strategy for a database creation and preservation of geological heritage in both individual countries and in the formation of a European registry of geosites. 
Ukraine is an active participant in the movement for the preservation of geological heritage and since 1992 representatives of Ukraine have taken part in it, starting from the first meeting of the European Working Group (EWGESC - future ProGEO) in England (Weymouth), the ProGEO session which took place in Hungary in 1994(Budapest), the General Assembly ProGEO held in Sweden and many others (in different years these representatives were Y. Zinko, A. Ivchenko, N. Gerasimenko, V. Gritsenko, V. Manyuk). In 1995, after the first meeting of the Central European Group (WG - Central European Working Group), it was joined by Ukraine. A specially designed course since 1997 has dealt with the problem of studying and preserving geosites in Ukraine, and in particular in the regions of Central and Eastern Ukraine (Dnepropetrovsk, Zaporizhye, Poltava, Sumy, Kharkiv, Donetsk and Crimea). Since 2000 Manyuk V. has been a member of ProGEO and participated in many symposiums, conferences and geological congresses. In May 2003, in Kiev, at a meeting of the State Geological Service of Ukraine an extremely important document was considered and adopted: «Comprehensive program of work on scientific and methodological support of regional geological studies in Ukraine.» The program focuses on the tasks that correspond to fundamental areas of geological science. Therefore, an important and timely step was the proposal of Manyuk V. for the inclusion in the draft program, as one of its objectives, of the problem of researching inventorising and creating a computer database of the geological monuments of Ukraine. The author of the proposal initiated and was involved the publication of a 4-volume monograph «Geological Monuments of Ukraine.» Therefore it is not by chance that at Dnipropetrovs'k National University, my proposal for a new course on geoconservation for 5th year students was accepted in 2011 and first implemented in the academic year 2012/13.

On the assumption that the geological environment is the most important component of the natural environment, the course deals with the concept of the Nature Reserve Fund of Ukraine (NRF), its structure and the stages of its historical development.

One of the themes of the new discipline is study of the basic provisions of the «The State Programme of National Ecological Network of Ukraine in the years 20002015», part of which are geosites. This Programme was adopted in accordance with the recommendations of the Pan-European Biological and Landscape Diversity Strategy for the Formation of a Pan-European Ecological Network.

The course covers the results in Ukraine in 2004-2006 of the revised survey of geological monuments (geosites), creating the basis for a computer database of these objects and the four-volume illustrated book «The Geological Monuments of Ukraine» in the Ukrainian and English languages [2].

The methodological principles of generating a network of geosites in Ukraine, their comparative evaluation for creation of local and national registers, the criteria for the selection of geosites for these levels, as well as for the European registry of geosites is dealt with in accordance with the recommendations set forth in the guide Problems of the Protection of the Geological Heritage of Ukraine [13].

Based on the analysis of the classifications of types of geosites used in the project GILGES, the working group of the Geological Museum of the National Academy of Sciences of Ukraine [3] and the classification adopted in the book Problems of the Protection of the Geological Heritage of Ukraine, a classification that includes the following 14 types has been agreed upon: stratigraphic, petrographic, mineralogical, paleontological, tectonic, volcanic, geomorphologic, karstic, geochronologic, glaciological, cosmological, mining-historical, hydrogeological and geoarchaeological. 
One of the themes of the course involves the study, consideration and use of the best international experience in the conservation of geological heritage, on the basis of numerous examples $[3 ; 5 ; 13 ; 14]$.

An important component of the course is the consideration and analysis of the legal and regulatory framework of Ukraine concerning objects of the Nature Reserve Fund in general and of the geological heritage in particular. First of all, this concerns the law of Ukraine «On the Nature Reserve Fund of Ukraine» (No. 2456-12 from 14/07/2011), «Classification of Territories and Objects of the Nature Reserve Fund of Ukraine», the legal foundations of the territories and objects of the Nature Reserve Fund (NRF), fixed assets of the protected territories and objects of the NRF, the form of ownership in the territory and objects, the usage of NRF territories and objects (for example: conservation, research, recreation, and educational use, monitoring of the environment), etc. [12].

The course includes familiarization with the regime of the territories and objects of the NRF, which is a set of science-based environmental requirements, norms and rules that would define the legal status of these territories and natural objects, the character of permissible activities within them, the protection regime, usage and restoration of natural systems.

The course surveys the stages in the creation and declaration of the territories and objects of the NRF, in general and in particular the geological reserves, geological natural monuments (geosites) from the filing of petitions for the organization and declaration of a protected NRF territory and object to the approval and confirmation of such measures by different levels of the executive power.

So, the decisions on the establishment of nature reserves, national parks, as well as other NRF territories and objects of national importance are taken by the President of Ukraine. Decisions on the organization or declaration of territories and objects of NRF objects of local significance are made at local government level.

Lecture notes written for the training course also include a list of geological monuments of Ukraine, with their official conservation status and of prospective geosites. Their territorial distribution is discussed and also their distribution by categories (local, state, international) and types (mineralogical, paleontological, stratigraphic and etc.) [2]. The course discussed in detail the problem of creation and development of a European and international network of geoparks, in the framework of which is assessed the prospects for creation of geoparks in Ukraine and identification of specific objects of primary importance, among which are the volcanic Karadag Massif in the Crimea, Podilski Tovtry within the Volyn-Podolsk plate, "Eagle's Nest" (a complex of geosites within the Kriviy Rig Precambrian iron ore basin on the Ukrainian shield), etc. This section provides information about the European Geoparks Network (EGN) and the global network of geoparks (GNG), as well as information about the history of their creation and a description of selected objects [11].

The summary of the lectures of the training course gives considerable attention to the potential of tourism of natural geological monuments with a view to their promotion and protection from damage and destruction [6].

The final section of the course aims to acquaint students with peculiarities of monitoring the geological heritage of Ukraine, carried out by the geological units of the State Geological Survey from 2006.

The objectives of the course involve an in-depth examination of the problem of the study, identification and preservation of natural geological monuments, the study of 
the history of geoconservation in Ukraine, Europe and the world; definition of what is meant by the term natural geological monument (geosite), familiarization with the classification of geosites by type and category; comparative assessment of geological sites and their distribution in Ukraine in accordance with structural and tectonic zoning; study of the evaluation criteria for geosites; potential of tourism for popularization of geosites; study of the legal framework for geoconservation in Ukraine and the role of geosites in forming the Nature Reserve Fund of Ukraine; introduction of an international project on establishment of national, European and international registries of geosites; providing students with a clear understanding of the problem and the prospects of establishing geological parks in Ukraine and their integration into the European and global network. The course is designed for students of the 5th year (Specialist and Master), enrolled in the direction "Geology" and consists of 108 hours of theoretical classes, 108 hours of practical training and 216 hours of independent work involving both work with the literature and computer databases and field trips to objects of geological heritage. The course is a compulsory element of the study process and is taught over a full academic year with optional summer geological practice, the purpose of which is the practical consolidation of the acquired knowledge.

Students carry out individual practical work in which they describe specific geosites of Ukraine in the form proposed in 1998 [4] with the clarifications of the author of the course. For the compilation of their descriptions they use data from the literature, web resources, and follow recommendations from their lecturers. The student individually determines the coordinates of the geosite he/she is researching, and includes in his/her work the appropriate fragment of the satellite image and of the topographic map where the specified object is shown. Photographs of the geological monument which give a clear and full image of its characteristics are included in the description as well as the appropriate fragments of geological maps and other illustrations which help to understand the geosite.

The student also identifies the category of the object of geological heritage (local, national, international), and whether it has potential for being classified as a geosite if it does not already have official conservation status. If the site described already does enjoy specific conservation status, a recommendation is made within the description to raise or maintain the existing level. For example, the author of the description can suggest for local object a conservation status at state or even international level, based on the criteria of selection of geosites for the appropriate category.

Students are assigned geosites of a specific type in accordance with the classification of objects (geomorphologic, stratigraphic, glacial, karstic, etc.). However, several types can be suggested with one main type being assigned for compulsory study.

Proceeding from the necessity of encouraging tourists to visit the objects of geological heritage, with a view to their promotion and preservation, an important component of the independent work of students is to collect information on other objects of interest for tourism located in the vicinity of geosites. These may be territories and objects of the Nature Reserve Fund (botanical, ornithological, forest, landscape, entomological, wetland wildlife refuges and natural monuments; parks, regional landscape parks, botanical gardens, parks, monuments of landscape gardening art, etc.), places connected with the history of the Zaporizhye Cossacks, historical battles, archeological, ethnic, historical and cultural monuments, religious, places of recreation, etc. (http://manuk-geo.ucoz.ua). 
Conclusion. The territory of Ukraine is characterized by a complex and diverse geological structure, rich in its mineral-raw-material base and a large number of unique objects of geological heritage (geosites). Since 2006 the country has organized monitoring of the geosites and the creation of a database of geological heritage. The introduction of the training program of the university disciplines «Study and Preservation of Natural Geological Monuments» is necessary and timely. Since the introduction of the course 35 students have been attracted to participate and they have given a highly positive evaluation of this educational discipline. Theoretical and practical classes have been very successful and popular with students. Many students have chosen to spend their summer vacation at unique geological heritage sites.The course is new, is still under development (in parallel with the teaching process) and therefore will be improved in order to fully cover all the features of geoconservation. As a result of the course the students receive, above all, an in-depth knowledge of the problem of the study and conservation of geological heritage, both in Ukraine and in other countries around the world, and come to recognize the importance of an attitude of care and responsibility both towards geosites and the natural environment in general. Work on geosites of various types and categories, with a wide stratigraphic range promotes the formation and dissemination of knowledge in many geological disciplines: stratigraphy, paleontology, geomorphology, petrography, mineralogy, deposit formation, volcanology, tectonics and many others. The great interest expressed by students in the course permits us to predict the possibility of its introduction in other universities and colleges which educate not only geologists of different specialties, but also specialists in geographical and environmental areas of study.

\section{References}

1. Andrasanu, A. Geoeducation - a key part of Geoconservation [Text]/ A. Andrasanu // Studia Universitatis Babeş-Bolyai, Geologia, Special Issue, MAEGS 16, 2009. - P. 5-7.

2. Geological Monuments (geosites) of Ukraine [Text]: in 4 vol./ V. Bezvynniy [et al]. - K.: DIA, 2006 - 011. - 280 p. (in Ukrainian, English).

3. Geological Natural Monuments of Ukraine: problems of study, preservation and rational use [Text]: V. Gritsenko, A. Ishchenko, U. Rusko, A. Shevchenko. - K.: CSNM NAN of Ukraine, 1995. - 61 p. (in Ukrainian).

4. Framework for Geosites in Northern Europe [Text]// C.E. Iohansson [et al]. Tallinn: ProGEO'97 in Estonia, 1997. - P. 22-29.

5. Ivchenko, A. Geological Heritage of Ukraine: studying international experience. [Text]: Geography and economic fundamentals in school./A. Ivchenko. - K.: Educational Media, 3, 1998. - №3. - P.7-8. (in Ukrainian).

6. Manyuk, V. Tourist aspects of using natural geological monuments [Text]/ V. Manyuk. In Proceedings «Sustainable development of tourism on the coast of the Black Sea »/- O.: Navch. knyga - P.175-181 (in Ukrainian).

7. Manyuk, V. Geological heritage of the southern part of Ukraine. Natural and Cultural landscapes [Text]: Proceedings of a conference/V. Manyuk. - Dublin Castle, 2004. - P. $93-98$.

8. Manyuk, V. Potential objects for Creation of a Network National Geoparks in Ukraine [Text]: ProGEO Symposium «Safeguarding our Geological Heritage»/ V. Manyuk. - K.: 2006. - P. 30-32. 
9. Manyuk, V. Historical Review of the Study of Geological Heritage in Ukraine [Text]: Proceedings of the Russian Group of ProGEO/V. Manyuk. - Miass: Geotur, 2007. - P. 47-49. (in Russian).

10. Manyuk, V. The Problem of Creation of a Network of National Geoparks in Ukraine [Text]/ Bulletin of the DNU/ V. Manyuk. - D.: DNU, 2007. - P. 63-67.

11. Manyuk, V. Historical Background to the Establishment of a National Geological Park «Eagle's Nest». Protection and the Management of Sites of Natural Beauty in the Protected Areas: Hrymayliv-Ternopil [Text]/ V. Manyuk. - Hrymayliv: Djura, 2008. - P.175-181(in Ukrainian).

12. Oxamytnyi, O. Legislatively-normative acts of Ukraine regarding the Organization of territories and objects of Natural Reserve Fund. [Text]: O. Oxamytnyi, O. Chircova, V. Manyuk. - D.: Lira - 2001. - P.102-144 (in Ukrainian).

13. Problems of conservation of the geological heritage of Ukraine [Text]/W.A.P. Wimbledon [et al]. - K.: DSC NASU, 1999. - P. 83-118.

14. Wimbledon, W.A.P. Geoheritage in Europe and its Conservation [Text]/ ed. W.A.P. Wimbledon, S. Smith-Meyer. - Oslo: ProGEO, 2012. - 405 p. 